\title{
Aromatic Acids in Urine of Healthy Infants, Persistent Hyperphenylalaninemia, and Phenylketonuria, before and after Phenylalanine Load
}

\author{
S. RAMPINI, ${ }^{(37)}$ J. A. VÖLlMIN, H. R. BOSSHARD, M. MÜLLER, AND H. C. CURTIUS
}

Department of Pediatrics of the University and of the Stadtspital Triemli, Zürich, Switzerland

\section{Extract}

Aromatic acids in urine were studied by gas chromatography and mass spectrometry in 3 premature and 7 full term healthy infants, in 2 patients with persistent hyperphenylalaninemia, and in 11 patients with phenylketonuria. Eleven aromatic acids were determined quantitatively.

On a free diet, patients with phenylketonuria excreted large amounts of phenylacetic, mandelic, phenyllactic, o-OHphenylacetic, and phenylpyruvic acids ("phenylketonuria metabolites"), whereas the two patients with persistent hyperphenylalaninemia showed only a slightly abnormal excretion of these compounds. No or only very small amounts of phenylketonuria metabolites were found in healthy infants on normal diet, as well as in patients with persistent hyperphenylalaninemia or phenylketonuria on low phenylalanine diet.

After an oral L-phenylalanine load $(100 \mathrm{mg} / \mathrm{kg})$ no or only a slight increase of phenylketonuria metabolites was observed in the urine during the subsequent $24 \mathrm{hr}$ in healthy infants on normal diet, as well as in the two patients with persistent hyperphenylalaninemia on low phenylalanine diet; in contrast, the concentration of these metabolites increased markedly in patients with phenylketonuria on low phenylalanine diet. This divergent response of the aromatic acids in urine to an oral phenylalanine load administered during a low phenylalanine diet probably represents a useful criterion for the differential diagnosis of these two conditions.

\section{Speculation}

The quantitative determination of the aromatic acids in urine before and after phenylalanine load can be considered as an indirect measurement of phenylalanine hydroxylase activity.

In phenylketonuria there is no demonstrable activity of hepatic phenylalanine hydroxylase $(9,15)$, the enzyme which converts phenylalanine to tyrosine. Phenylalanine is metabolized by alternate minor pathways and significant amounts of several unusual but not abnormal metabolites are formed and excreted in urine (see reviews in References 20 and 27).

In persistent hyperphenylalaninemia $(1-4,6-7,11-14,17$, $21-24,28-31,35,36)$, the activity of the phenylalanine hydroxylase seems to be decreased but not totally absent, as demonstrated by enzyme assays in a few studies $(16,17,19$ 30). The level of phenylalanine in plasma rises rather slowly after birth and remains subsequently mostly between 4 and 15 $\mathrm{mg} / 100 \mathrm{ml}$. On a normal protein intake, it only rarely rises to 20 or more $\mathrm{mg} / 100 \mathrm{ml}$. The urine tests for aromatic acids $\left(\mathrm{FeCl}_{3}, \mathrm{DNPH}\right.$, Phenistix) are usually negative and, with few exceptions $(1,14,28,36), o-\mathrm{OH}$-phenylacetic acid as well as phenylpyruvic acid are not detectable by paper chromatography $(12,17,29,30)$ or spectrophotometry (1). However, abnormal amounts of aromatic acids can always be demonstrated after a phenylalanine load $(1,17,24,28,30,35,36)$. Most patients, whether on or off a diet, perform within the average range of intelligence (3).

Persistent hyperphenylalaninemia has to be distinguished from other disorders of phenylalanine metabolism such as phenylalanine transaminase deficiency and transient hyperphenylalaninemia (see reviews in References 13 and 23). Patients with persistent hyperphenylalaninemia probably represent a biochemically and genetically heterogeneous group.

In the present study, aromatic acids in urine were determined quantitatively by gas chromatography and identified by mass spectrometry. The investigation was performed in healthy infants, as well as in patients with persistent hyperphenylalaninemia and phenylketonuria, before and after a phenylalanine load. The patients were studied while on and off a low phenylalanine diet.

\section{SUBJECTS AND METHODS}

Aromatic acid excretion in urine was studied in 3 healthy premature infants, aged 2-5.5 weeks (weight at birth $1,580-2,180 \mathrm{~g}$; at examination $2,990-2,500 \mathrm{~g}$ ), in healthy full term infants, aged $1-9$ months (weight $3,320-9,300 \mathrm{~g}$ ), in 2 patients with persistent hyperphenylalaninemia, aged 2-4 months, and in 11 patients with phenylketonuria, aged 11 days -11.75 years. For better comparison, the healthy subjects were chosen from the same age group as the two patients with persistent hyperphenylalaninemia. These two cases are as follows.

\section{CASE LA}

A girl, birth weight $3,270 \mathrm{~g}$, first-born of healthy Italian parents, had no family history of phenylketonuria, mental retardation, or consanguinity. She was breast fed, and the Guthrie test at 6,10 , and 13 days was $5-6 \mathrm{mg} / 100 \mathrm{ml}$ phenylalanine. At 18 days she was placed on a cow's milk preparation (protein $4.9 \mathrm{~g} / \mathrm{kg} / 24 \mathrm{hr}$ ); at 24 days the Guthrie test showed a level of phenylalanine in blood of about 20 $\mathrm{mg} / 100 \mathrm{ml}$, and column chromatography a concentration of 
$11 \mathrm{mg} / 100 \mathrm{ml}$ at 27 days and of $19.7 \mathrm{mg} / 100 \mathrm{ml}$ at 29 days. She was then started on a low phenylalanine diet; the level of phenylalanine in plasma fell to $1.46 \mathrm{mg} / 100 \mathrm{ml}$ within 2 days. The phenylalanine intake with the diet was increased gradually to $100 \mathrm{mg} / \mathrm{kg} / 24 \mathrm{hr}$ and the level of phenylalanine in plasma remained between 3.96 and $11.87 \mathrm{mg} / 100 \mathrm{ml}$ (column chromatography). From the age of 3.75 months, she was given a free diet and the mean level of phenylalanine in plasma did not increase; however, occasional peaks occurred, especially with infections. The $\mathrm{FeCl}_{3}, \mathrm{DNPH}$, and Phenistix tests were persistently negative, EEGs at 1 month and at 3.5 years were normal. Height and weight within the low normal range. DQ was 92 at 5.5 months and 100 at 7.5 months; IQ was 102 at 3.5 years.

\section{CASE SR}

This child, a boy, birth weight $3,300 \mathrm{~g}$, was the first child of unrelated Swiss parents; there was no family history of phenylketonuria or mental retardation. With breast feeding, the level of phenylalanine in plasma was about $5 \mathrm{mg} / 100 \mathrm{ml}$; at 3 months, after 1 month of feeding with a protein-rich cow's milk preparation, the phenylalanine concentration rose to $19.6 \mathrm{mg} / 100 \mathrm{ml}$. After a period on a low phenylalanine diet, the phenylalanine intake was gradually increased to 100 $\mathrm{mg} / \mathrm{kg} / 24 \mathrm{hr}$ and the level of phenylalanine in plasma from 3.77 to $6.43 \mathrm{mg} / 100 \mathrm{ml}$. At $3.75 \mathrm{months}$ he was placed on a free diet, and the level of phenylalanine in plasma generally remained between 3.38 and $8.17 \mathrm{mg} / 100 \mathrm{ml}$ with occasional peaks to $13.13 \mathrm{mg} / 100 \mathrm{ml}$ (column chromatography). At 8 months, the child was started on a low protein diet $(2.1$ $\mathrm{g} / \mathrm{kg} / 24 \mathrm{hr}$ ), which was later completed with a phenylalaninefree mixture. The $\mathrm{FeCl}_{3}, \mathrm{DNPH}$, and Phenistix test were always negative. EEGs at 4 and 5.5 months were normal. Height and weight were normal. DQ was 82 at 5.5 months and 104 at 8.5 months; IQ was 105 at 3 years 7 months.

L-Phenylalanine $(100 \mathrm{mg} / \mathrm{kg}$ body $\mathrm{wt})$ was administered in water or in a $1 / 1$ mixture of water and orange juice, 200 $\mathrm{ml} / \mathrm{m}^{2}$ after an overnight fast. The phenylalanine load was performed in healthy infants (9 of the 10 subjects) while on a normal diet, and in the 2 patients with persistent hyperphenylalaninemia while on a low phenylalanine and on a free diet. Two patients with phenylketonuria were investigated when on and off the diet; five were on diet only, and the remaining four were on a free diet.

The level of phenylalanine in plasma was determined by column chromatography with a short program, as described previously (25).

Aromatic acids were determined in the urine samples of 24 $\mathrm{hr}$ before, and in those of the first $4 \mathrm{hr}$ and the subsequent 20 hr after load, using the method published previously (32) except for the following: $15 \mathrm{ml}$ instead of $10 \mathrm{ml}$ ethyl acetate was used three times for the extraction. The silylation was carried out for $15 \mathrm{~min}$ with $0.1 \mathrm{ml}$ bis(trimethylsilyl)trifluoroacetamide at room temperature. Gas chromatography was performed with glass columns XE $603 \%$ on Gaschrom Q 80-100 mesh ( $2 \mathrm{~m}$ by $2.7 \mathrm{~mm}$ inner diameter), using a temperature program of $2^{\circ} / \mathrm{min}, 90-220^{\circ}$; injector, $250^{\circ}$; detector, $230^{\circ}$

When 0 -hydroxyphenylacetic acid was added to urine before extraction, the recovery in 10 separate determinations was about $80 \%$. To overcome losses during the extraction procedure, the calibration curves were established by analyzing the test mixture by the procedure mentioned above. The variation coefficient of 10 determinations in the same urine was $8.2 \%$

\section{RESULTS}

\section{PHENYLALANINE CONCENTRATIONS IN PLASMA}

Phenylalanine concentrations (mean and $s$ ) before and after load of the children with phenylketonuria and of the two patients with persistent hyperphenylalaninemia are shown in Tables 1 and 2 . The values before and $1,2,3$, and $4 \mathrm{hr}$ after loading, as well as the difference between the postloading concentrations of the first $4 \mathrm{hr}$ and the zero time values of the two groups on diet are not significantly different $(P>0.1)$. Only the corresponding values $24 \mathrm{hr}$ after loading are higher in the patients with phenylketonuria $(0.01<P<0.05)$.

\section{AROMATIC ACIDS IN URINE}

Aromatic acids which could be demonstrated with this method and their concentration (micrograms per milligram of creatinine) in urine of the three groups of subjects studied are shown in Tables 3-6. The sensitivity of the method used allows to calculate amounts as small as $1 \mu \mathrm{g} / \mathrm{mg}$ creatinine; smaller but clearly detectable quantities are listed in the tables as $<1 \mu \mathrm{g} / \mathrm{mg}$ creatinine. For the calculation of mean and standard deviation, values $<1$ were assumed to be $0.5 \mu \mathrm{g} / \mathrm{mg}$ creatinine. The range of the individual values was rather large, but there was no relation between the concentration of the aromatic acids in urine $(\mu \mathrm{g} / \mathrm{mg}$ creatinine $)$ and the age of the patients.

Table 1. Oral L-phenylalanine load on free diet ${ }^{1}$

\begin{tabular}{|c|c|c|c|c|c|c|}
\hline & \multicolumn{6}{|c|}{ Phenylalanine in plasma, $\mathrm{mg} / 100 \mathrm{ml}$} \\
\hline & $0 \mathrm{hr}$ & $1 \mathrm{hr}$ & $2 \mathrm{hr}$ & $3 \mathrm{hr}$ & $4 \mathrm{hr}$ & $24 \mathrm{hr}$ \\
\hline \multicolumn{7}{|c|}{ Phenylketonuria } \\
\hline Mean & 37.82 & 55.97 & 60.54 & 56.44 & 61.59 & 47.32 \\
\hline s & 22.20 & 30.29 & 21.53 & 25.85 & 25.58 & 25.46 \\
\hline \multicolumn{7}{|c|}{$\begin{array}{l}\text { Persistent hyper- } \\
\text { phenylala- } \\
\text { ninemia }\end{array}$} \\
\hline Mean & 11.87 & 29.17 & 28.04 & 29.23 & 27.62 & 15.14 \\
\hline s & 1.63 & 6.83 & 7.26 & 7.22 & 5.33 & 4.10 \\
\hline
\end{tabular}

${ }^{1}$ Phenylalanine in plasma (milligrams per $100 \mathrm{ml}$; mean and $\mathrm{s}$ ) in six patients with phenylketonuria and two with persistent hyperphenylalaninemia.

Table 2. Oral L-phenylalanine load on low phenylalanine diet ${ }^{1}$

\begin{tabular}{|c|c|c|c|c|c|c|}
\hline & \multicolumn{6}{|c|}{ Phenylalanine in plasma, $\mathrm{mg} / 100 \mathrm{ml}$} \\
\hline & $0 \mathrm{hr}$ & $1 \mathrm{hr}$ & $2 \mathrm{hr}$ & $3 \mathrm{hr}$ & $4 \mathrm{hr}$ & $24 \mathrm{hr}$ \\
\hline \multicolumn{7}{|c|}{ Phenylketonuria } \\
\hline \multicolumn{7}{|c|}{ Phenylalanine } \\
\hline Mean & 3.25 & 19.34 & 19.69 & 21.61 & 21.03 & 18.13 \\
\hline s & 2.33 & 6.91 & 6.96 & 5.50 & 6.14 & 4.73 \\
\hline \multicolumn{7}{|c|}{$\begin{array}{l}\text { Postload con- } \\
\text { centration }{ }^{2}\end{array}$} \\
\hline Mean & & 16.09 & 16.44 & 18.36 & 17.78 & 14.88 \\
\hline $\mathrm{s}$ & & 5.10 & 5.55 & 4.47 & 4.58 & 4.27 \\
\hline \multicolumn{7}{|c|}{$\begin{array}{l}\text { Persistent hyper- } \\
\text { phenylala- } \\
\text { ninemia }\end{array}$} \\
\hline \multicolumn{7}{|c|}{ Phenylalanine } \\
\hline Mean & 4.46 & 20.27 & 19.69 & 20.33 & 18.55 & 11.51 \\
\hline $\mathrm{s}$ & 2.14 & 2.41 & 1.33 & 4.08 & 0.46 & 0.77 \\
\hline \multicolumn{7}{|c|}{$\begin{array}{l}\text { Post-load con- } \\
\text { centration }\end{array}$} \\
\hline Mean & & 15.81 & 15.23 & 16.36 & 14.08 & 7.05 \\
\hline $\mathrm{s}$ & & 0.26 & 0.80 & 1.94 & 1.67 & 2.91 \\
\hline
\end{tabular}

${ }^{1}$ Phenylalanine in plasma (milligrams per $100 \mathrm{ml}$; mean and $\mathrm{s}$ ) in seven patients with phenylketonuria and two with persistent hyperphenylalaninemia.

${ }^{2}$ Zero time value. 
Table 3. Aromatic acids in urine in six patients with phenylketonuria on free diet before and after phenylalanine load

\begin{tabular}{|c|c|c|c|c|c|c|c|c|c|}
\hline & & & & \multicolumn{6}{|c|}{ Creatinine level after load, $\mu \mathrm{g} / \mathrm{mg}$} \\
\hline & \multicolumn{3}{|c|}{ Basal $^{1}$ creatinine level } & \multicolumn{3}{|c|}{$0-4 \mathrm{hr}$} & \multicolumn{3}{|c|}{$4-24 \mathrm{hr}$} \\
\hline & Mean & $\mathrm{s}$ & Range & Mean & $\mathrm{s}$ & Range & Mean & s & Range \\
\hline Phenylacetic acid & 46 & 17 & $16-62$ & 71 & 36 & $42-138$ & 88 & 51 & $16-168$ \\
\hline Mandelic acid & 19 & 7.7 & $10-30$ & 46 & 30 & $18-96$ & 48 & 27 & $20-98$ \\
\hline Phenyllactic acid & 531 & 735 & $29-1,820$ & 1,156 & 1,500 & $95-3,336$ & 1,170 & 1,108 & $140-2,940$ \\
\hline$o$-Hydroxyphenylacetic acid & 65 & 27 & $33-110$ & 131 & 80 & $72-282$ & 204 & 132 & $102-460$ \\
\hline$p$-Hydroxyphenylacetic acid & 60 & 89 & $14-240$ & 64 & 93 & $13-250$ & 62 & 61 & $17-178$ \\
\hline Phenylpyruvic acid & 371 & 363 & $33-1,010$ & 1,068 & 767 & $162-1,812$ & 1,282 & 1,076 & $168-2,680$ \\
\hline$m$-Hydroxyphenylhydracrylic acid & 12 & 8.3 & $2.5-24$ & 24 & 16 & $5.8-46$ & 15 & 7.7 & $5.6-26$ \\
\hline Homovanillic acid & 8.2 & 2.8 & $3.8-12$ & 7.9 & 3.8 & $3.6-14$ & 12 & 6.2 & $1.8-18$ \\
\hline$p$-Hydroxyphenyllactic acid & 121 & 159 & $22-440$ & 120 & 152 & $15-420$ & 225 & 198 & $26-540$ \\
\hline 3-Methoxy-4-hydroxymandelic acid & 8.0 & 2.4 & $6-11$ & 27 & 26 & $7-78$ & 16 & 7.8 & $5.4-26$ \\
\hline$p$-Hydroxyphenylpyruvic acid & 39 & 33 & $10-96$ & 53 & 43 & $14-132$ & 53 & 32 & $24-96$ \\
\hline
\end{tabular}

${ }^{1}$ For the individual values see Reference 31.

Table 4. Aromatic acids in urine in healthy infants before and after phenylalanine load

\begin{tabular}{|c|c|c|c|c|c|c|c|c|c|}
\hline & \multirow{2}{*}{\multicolumn{3}{|c|}{$\operatorname{Basal}(\mathrm{n}=10)^{2}$}} & \multicolumn{6}{|c|}{ Creatinine level after load $(\mathrm{n}=9), \mu \mathrm{g} / \mathrm{mg}$} \\
\hline & & & & \multicolumn{3}{|c|}{$0-4 \mathrm{hr}$} & \multicolumn{3}{|c|}{$4-24 \mathrm{hr}$} \\
\hline & Mean & s & Range & Mean & s & Range & Mean & s & Range \\
\hline Phenylacetic acid & 0.1 & 0.3 & $\mathrm{nd}^{2}-1.1$ & 0.3 & 0.9 & $\mathrm{nd}-2.6$ & 0.2 & 0.7 & nd -2.0 \\
\hline Mandelic acid & 1.1 & 0.7 & nd -1.9 & 2.0 & 1.3 & nd -4.1 & 1.5 & 1.1 & nd -3.7 \\
\hline Phenyllactic acid & 1.8 & 1.3 & $<1-5$ & 1.6 & 1.0 & $<1-3.2$ & 1.8 & 1.2 & $<1-4$ \\
\hline$o$-Hydroxyphenylacetic acid & 1.3 & 1.8 & $<1-6.1$ & 1.6 & 1.3 & $<1-4.2$ & 0.8 & 0.5 & $<1-1.8$ \\
\hline$p$-Hydroxy phenylacetic acid & 60 & 39 & $21-140$ & 93 & 95 & $2.1-314$ & 76 & 49 & $21-182$ \\
\hline Phenylpyruvic acid & 0.3 & 0.4 & nd -1.4 & 0.3 & 0.5 & nd -1.4 & 0.2 & 0.3 & nd $-<1$ \\
\hline$m$-Hydroxyphenylhydracrylic acid & 3.9 & 5.5 & nd -17 & 8.7 & 12 & nd -35 & 5.2 & 7.8 & nd -20 \\
\hline Homovanillic acid & 17 & 11 & $3.5-45$ & 22 & 12 & $10-44$ & 16 & 5.4 & $6.7-22$ \\
\hline$p$-Hydroxyphenyllactic acid & 28 & 34 & $4-110$ & 54 & 124 & $4.4-384$ & 36 & 49 & $3.6-146$ \\
\hline 3-Methoxy-4-hydroxymandelic acid & 8.9 & 3.0 & $2.8-13$ & 9.0 & 3.2 & $4.8-14$ & 8.6 & 3.1 & $4.8-14$ \\
\hline$p$-Hydroxyphenylpyruvic acid & 15 & 29 & $<1-92$ & 32 & 79 & $<1-242$ & 17 & 27 & $<1-78$ \\
\hline
\end{tabular}

${ }^{1}$ For the individual values see Reference 31.

${ }^{2}$ nd: not detectable.

The amount of excretion of the aromatic acids was expressed in micrograms per milligram of creatinine because the subjects were of different ages and consequently the data of the total excretion per $24 \mathrm{hr}$ would not be sufficiently representative.

Hippuric acid was also present in all subjects, but the quantity was not calculated. Some results (individual values of the patients with phenylketonuria on free diet before phenylalanine load and of the healthy infants before load) have already been published in a communication concerning methodology (32).

According to their behavior, the aromatic acids demonstrated with this method can be subdivided into three groups.

Group I: Phenylketonuria Metabolites. In untreated phenylketonuria, as shown in Table 3, phenylacetic, mandelic, phenyllactic, $O-\mathrm{OH}-\mathrm{phenylacetic,} \mathrm{and} \mathrm{phenylpyruvic} \mathrm{acids} \mathrm{are}$ excreted in large amounts. The urine concentration of these compounds showed no relation to the age of the patients. These five aromatic acids will hence be called phenylketonuria metabolites; their level of excretion was different in the three groups of subjects investigated.

Group Ia: Healthy Infants (Table 4). No or only small amounts of phenylketonuria metabolites were excreted by these children before a phenylalanine load, and no or only a slight increase was observed after load. There was no difference between premature and full term infants.
Group Ib: Patients with Persistent Hyperphenylalaninemia (Table 5). An excretion pattern similar to that in healthy infants was found in these children while they were on low phenylalanine diet (before and after phenylalanine load); however, on free diet, some phenylketonuria metabolites were excreted in slightly abnormal amount before the load and there was a marked increase after the load.

Group Ic: Patients with Phenylketonuria. On low phenylalanine diet (Table 6), as expected, no or only small amounts of phenylketonuria metabolites were excreted before the load; however, in contrast to the findings in patients with persistent hyperphenylalaninemia, the concentration of these metabolites increased strongly after load. On the free diet (Table 3) the excretion was high before load and increased further after the load.

Group II: p-OH-Phenyllactic Acid and p-OH-Phenylpyruvic Acid. The mean excretion of these two aromatic acids was significantly higher in children with phenylketonuria on a free diet than in healthy full term infants. These substances are not phenylalanine metabolites; their abnormal excretion in phenylketonuria is probably caused by a secondary inhibition of metabolic pathways of tyrosine by some phenylalanine metabolites, what has also been recently studied by administration of deuterated phenylalanine (8).

Two healthy premature infants showed a level of excretion of $p$-OH-phenyllactic acid and $p$-OH-phenylpyruvic acid similar 
to that of the children with phenylketonuria. Furthermore, there was an increase of these metabolites in urine after a phenylalanine load in some but not all patients with phenylketonuria while they were on a free diet, but not while they were on a low phenylalanine diet, and there was a very slight increase in the two children with persistent hyperphenylalaninemia while they were on a free diet. For these reasons, $p$-OH-phenyllactic acid and $p$-OH-phenylpyruvic acid were not included in the group of the phenylketonuria metabolites for the purposes of this report.

Group IIII: Other Metabolites. The excretion of the other aromatic acids showed no difference in the three groups of subjects studied, either before or after phenylalanine loading. No values are presented for $m$-OH-phenylacetic acid, as the mass spectrometric analysis revealed that the corresponding peak was not only a signal of this, but also of another unknown compound.

Other phenylketonuria metabolites, such as phenylacetylglutamine, are not detectable with the method employed. The reported values for phenylacetic acid do not include phenylacetic acid other than phenylacetylglutamine.

\section{DISCUSSION}

BASAL AROMATIC ACIDS EXCRETION IN HEALTHY INFANTS, PERSISTENT HYPERPHENYLALANINEMIA, AND PHENYLKETONURIA

Gas chromatography allows an accurate quantitative analysis of acids in urine. In phenylketonuria, this method was used by Williams and Sweeley (34), Karoum et al. (18), Blau (5), and Wadman et al. (33).

Our findings in this disease (Table 3 ) confirm the results obtained by previous authors with other techniques, mainly paper chromatography (see review in References 20 and 27), i.e., an abnormally high level of excretion of phenylacetic, phenyllactic, $o-\mathrm{OH}$-phenylacetic, and phenylpyruvic acid. Like Blau (5) and Wadman et al. (33), who also used gas chromatography, we found a constantly abnormal excretion of mandelic acid. This compound must therefore be considered as a further characteristic metabolite in phenylketonuria (phenylketonuria metabolites)

Healthy infants on a normal diet (Table 4), as well as patients with persistent hyperphenylalaninemia (Table 5) or phenylketonuria (Table 6, References 5 and 33) on a low phenylalanine diet excrete no or only very small amounts of these substances. A marked difference between the patients with persistent hyperphenylalaninemia and those with phenyl- ketonuria can be observed while these children are on a free diet; in fact the former excrete only relatively small amounts of phenylketonuria metabolites (Table 5). Furthermore, Blau (5) found a normal aromatic acid excretion in three patients with hyperphenylalaninemia because the increased level of phenylalanine in plasma in persistent hyperphenylalaninemia is in general moderate and insufficient to cause significant overproduction of unusual metabolites.

\section{AROMATIC ACIDS EXCRETION AFTER PHENYLALANINE LOAD}

In urine collected after a phenylalanine load, different excretion patterns could be found in healthy infants, the two patients with persistent hyperphenylalaninemia, and the children with phenylketonuria (Tables $3-6$ ). The results in these three groups of subjects are summarized in Table 7 . With respect to the differential diagnosis between persistent hyperphenylalaninemia and phenylketonuria, the findings for a low phenylalanine diet are of particular interest. In both diseases, no or only very small amounts of phenylketonuria metabolites are excreted before a phenylalanine load; after the load, a high increase of these aromatic acids takes place in phenylketonuria, whereas in persistent hyperphenylalaninemia, no significant change occurs (Tables 5 and 6).

The quantitative determination of aromatic acids in urine may be considered to be an indirect measurement of the phenylalanine hydroxylase activity (Table 7). If this enzyme system is normal, as in healthy infants, the loading dose of 100 mg phenylalanine/kg body wt will be metabolized without formation of phenylketonuria metabolites. In heterozygotes for phenylketonuria, we found, after a load, a slightly higher mean excretion of $O-\mathrm{OH}$-phenylacetic acid than in normal subjects, but there was an overlap of several values of the two groups (26)

In persistent hyperphenylalaninemia the phenylalanine hydroxylase activity is decreased markedly but is not totally absent $(16,17,19,30)$. The remaining enzyme activity is nearly sufficient to metabolize the phenylalanine contained in a normal diet. The two patients with persistent hyperphenylalaninemia are able to metabolize a loading phenylalanine dose also, when they are on low phenylalanine diet, but not when they are on a free diet. In this last condition of testing, phenylketonuria metabolites are excreted in significant amounts; the aromatic acids excretion pattern is identical with that in phenylketonuria. Güttler and Wamberg (11) also found a high excretion of $o-\mathrm{OH}$-phenylacetic acid (photometric

Table 5. Aromatic acids in urine in two patients with persistent hyperphenylalaninemia before and after phenylalanine load ${ }^{1}$

\begin{tabular}{|c|c|c|c|c|c|c|}
\hline & \multicolumn{3}{|c|}{ Creatinine level on low phenylalanine diet, $\mu \mathrm{g} / \mathrm{mg}$} & \multicolumn{3}{|c|}{ Creatinine level on free diet, $\mu \mathrm{g} / \mathrm{mg}$} \\
\hline & \multirow[b]{2}{*}{ Basal } & \multicolumn{2}{|c|}{ After load } & \multirow[b]{2}{*}{ Basal } & \multicolumn{2}{|c|}{ After load } \\
\hline & & $0-4 \mathrm{hr}$ & $4-24 \mathrm{hr}$ & & $0-4 \mathrm{hr}$ & $4-24 \mathrm{hr}$ \\
\hline Phenylacetic acid & $\mathrm{nd}^{2}$ & nd & nd & $1.8-2.7$ & $50-108$ & $56-120$ \\
\hline Mandelic acid & $<1-4.2$ & $2.4-3$ & $<1-3.8$ & $<1-8$ & $2-12$ & $4-28$ \\
\hline Phenyllactic acid & $<1-3.4$ & $<1-1.8$ & $<1-1$ & $3.3-4$ & $12-20$ & $16-38$ \\
\hline$o$-Hydroxyphenylacetic acid & $<1-2.2$ & $1-1$ & $<1-4.9$ & $6-18$ & $38-54$ & $62-168$ \\
\hline$p$-Hydroxyphenylacetic acid & $36-51$ & $16-66$ & $22-92$ & $36-48$ & $50-58$ & $68-90$ \\
\hline Phenylpy ruvic acid & nd & nd & nd $-<1$ & $<1-4$ & $28-42$ & $34-128$ \\
\hline$m$-Hydroxyphenylhydracrylic acid & $2.6-6.2$ & $<1-10$ & $2.2-7.4$ & $<1-2.8$ & $<1-<1$ & $<1-<1$ \\
\hline Homovanillic acid & $5.9-12$ & $7.4-7.6$ & $6.6-11$ & $6-13$ & $10-16$ & $16-20$ \\
\hline$p$-Hydroxyphenyllactic acid & $1.1-14$ & $3-4.6$ & $3.8-5.9$ & $10-17$ & $18-20$ & $24-28$ \\
\hline 3-Methoxy-4-hydroxymandelic acid & $7.4-22$ & $8.4-12$ & $8.8-11$ & $<1-10$ & $4-8$ & $4-12$ \\
\hline$p$-Hydroxyphenylpy ruvic acid & $1.5-7.4$ & $<1-<1$ & $<1-9.2$ & $<1-10$ & $4-34$ & $17-26$ \\
\hline
\end{tabular}

\footnotetext{
${ }^{1}$ Individual values for the two patients with persistent hyperphenylalaninemia.
}

${ }^{2}$ nd: not detectable. 
Table 6. Aromatic acids in urine in seven patients with phenylketonuria on low phenylalanine diet before and after phenylalanine load

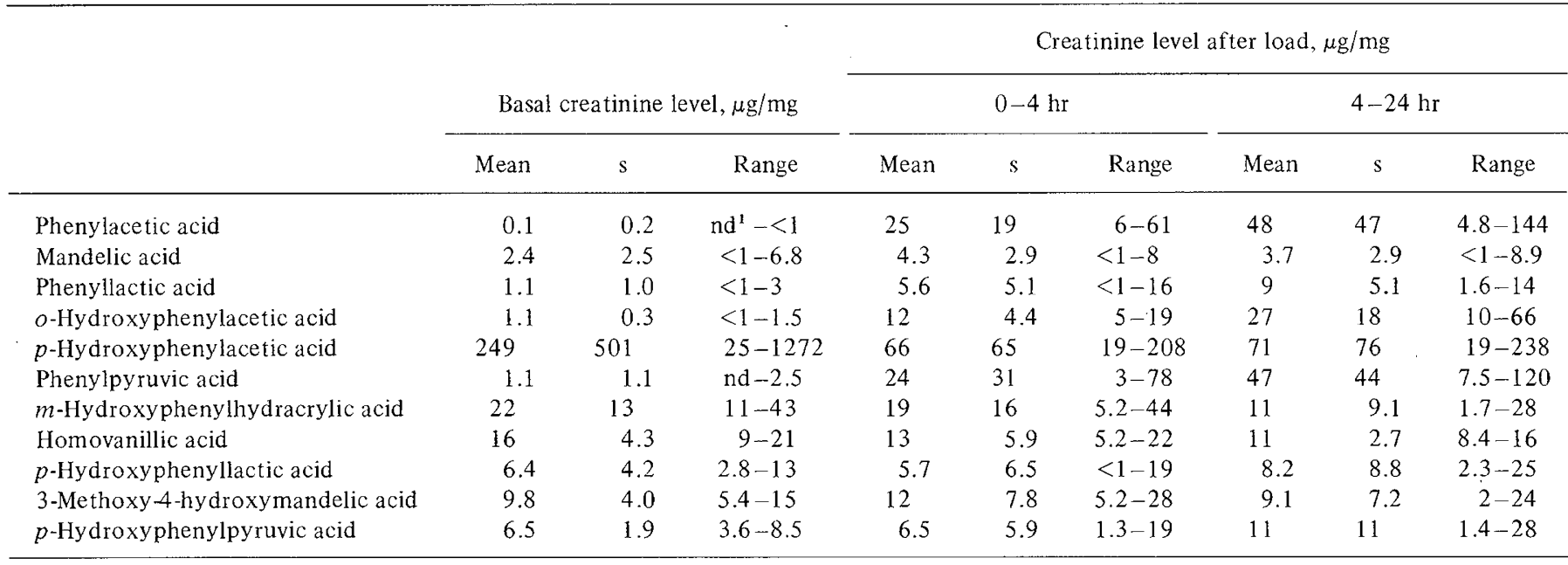

1 nd: not detectable.

method) in three patients with persistent hyperphenylalaninemia after a load performed on a free diet.

In phenylketonuria, there is no demonstrable phenylalanine hydroxylase activity; unusual metabolites will be excreted in each instance in which this enzyme system is necessary to metabolize phenylalanine, i.e., on a free diet (before and after loading) as well as after loading when the patients are on a low phenylalanine diet.

It should be pointed out that determination of aromatic acids in urine may be considered as an indirect measurement of the phenylalanine hydroxylase activity only if the metabolic defect in the subjects investigated is limited to this enzymatic system; we have no biochemical reasons to assume the presence of additional metabolic defects in our patients.

The analysis of aromatic acids in urine before and after load appears to represent a useful criterion to distinguish persistent hyperphenylalaninemia from phenylketonuria. However, as we had the opportunity to study only two patients with persistent hyperphenylalaninemia and because patients with this disorder probably constitute a heterogeneous group, conclusions from this investigation may be extended to all cases of persistent hyperphenylalaninemia with caution only.

RELATION BETWEEN PIASMA PHENYLALANINE IN PLASMA AND AROMATIC ACIDS IN URINE AFTER LOAD PERFORMED WITH DIET IN PATIENTS WITH PHENYLKETONURIA AND PERSISTENT HYPERPHENYLALANINEMIA

The phenylalanine concentrations before and during the first $4 \mathrm{hr}$ after the load performed on a diet (Table 2) allow no discrimination of the two patients with persistent hyperphenylalaninemia from those with phenylketonuria. Only the values $24 \mathrm{hr}$ after loading were higher in the phenylketonurics. These results are in agreement with the findings of Blaskovics and Shaw (4) and Güttler and Wamberg (11).

In spite of the similar values for phenylalanine in plasma during the first $4 \mathrm{hr}$ after load, the aromatic acids excretion within this time was markedly different in the two groups (Tables 5 and 6). Although the data of the present investigation do not offer a clear explanation of this fact, some possible mechanisms are discussed briefly.

The low phenylalanine hydroxylase activity present in the patients with persistent hyperphenylalaninemia is not or only scarcely utilized for the metabolism of the phenylalanine contained in a strong controlled diet. It is conceivable that this still available enzymatic activity allows a gradual conversion of the loading phenylalanine to tyrosine; this could explain the
Table 7. Phenylketonuria metabolites in healthy infants and in patient with persistent hyperphenylalaninemia and phenylketonuria, before and after phenylalanine load ${ }^{1}$

\begin{tabular}{lcc}
\hline & Basal & $\begin{array}{c}\text { After } \\
\text { phenylalanine } \\
\text { load }\end{array}$ \\
\hline $\begin{array}{l}\text { Healthy infants (PH normal) } \\
\text { Persistent hyperphenylala- } \\
\quad \text { ninemia (PH decreased) }\end{array}$ & $\mathrm{nd} / \mathrm{sa}$ & $\mathrm{nd} / \mathrm{sa}$ \\
$\begin{array}{l}\text { On low phenylalanine diet } \\
\text { On free diet }\end{array}$ & $\mathrm{nd} / \mathrm{sa}$ & $\mathrm{nd} / \mathrm{sa}$ \\
Phenylketonuria (no PH & $\mathrm{nd} /(+)$ & $+/++$ \\
$\quad$ activity) & & \\
$\begin{array}{l}\text { On low phenylalanine diet } \\
\text { On free diet }\end{array}$ & $\mathrm{nd} / \mathrm{sa}$ & $+/++$ \\
\hline
\end{tabular}

${ }^{1} \mathrm{PH}$ : phenylalanine hydroxylase; nd: not detectable; sa: small amounts.

absence of phenylalanine metabolites in urine after a load which is performed on a diet. The high tolerance for the phenylalanine of an unrestricted diet of these children was also explained by this mechanism (11).

Another possibility could be the presence in hyperphenylalaninemics of a mechanism for the elimination of phenylalanine different from that in patients with phenylketonuria. Lines and Waisman (22) found that the excretion of phenylalanine in urine (milligrams per gram of creatinine) of patients with hyperphenylalaninemia was not statistically different from that of children with phenylketonuria off diet, although the level phenylalanine in plasma was reduced by half. This fact prompted the hypothesis that patients with hyperphenylalaninemia could be protected by a high level of excretion of phenylalanine. On the other hand, Güttler and Rosleff (10) showed that the amount of phenylalanine in urine after a load was lower in five children with persistent hyperphenylalaninemia off diet than in eight children with phenylketonuria on diet, in spite of similar values for phenylalanine in plasma $1 \mathrm{hr}$ after loading. We have not determined the level of excretion of phenylalanine in urine in our patients.

Until now, no data support the hypothesis that another metabolic pathway for phenylalanine degradation may exist in patients with persistent hyperphenylalaninemia or that the phenylketonuria metabolites are unusually quickly metabolized in these patients. 


\section{SUMMARY}

The aromatic acids in urine were studied by gas chromatography and mass spectrometry in 10 healthy infants, 2 patients with persistent hyperphenylalaninemia, and 11 patients with phenylketonuria. The investigations were performed before and after a phenylalanine load, and in the patients while they were on and off a low phenylalanine diet. Eleven aromatic acids were determined quantitatively.

On a free diet, a highly abnormal level of excretion of phenylacetic, mandelic, phenyllactic, $o-\mathrm{OH}$-phenylacetic, and phenylpyruvic acids was found in phenylketonuria (phenylketonuria metabolites), whereas patients with persistent hyperphenylalaninemia excreted only slightly abnormal amounts of these compounds. The main difference between these two conditions was observed after the phenylalanine load, when the patients were given a low phenylalanine diet. In both diseases, no or only very small amounts of phenylketonuria metabolites were excreted before phenylalanine loading; after loading, a marked increase of these metabolites in urine was observed in phenylketonuria, while no significant change occurred in persistent hyperphenylalaninemia. The difference in behavior could be used as a differential diagnostic criterion between the two diseases.

\section{REFERENCES AND NOTES}

1. Auerbach, V. H., Di George, A. M., and Carpenter, G. G.: Phenylalaninemia: A study of the diversity of disorders which produce elevation of blood concentration of phenylalanine. In: W. L. Nyhan: Amino Acid Metabolism and Genetic Variation, p. 11 (McGraw-Hill, New York, 1967).

2. Berman, J. L., Cunningham, G. C., Day, R. W., Ford, R., and Hsia, D. Y.-Y.: Causes for high phenylalanine with normal tyrosine: In newborn screening programs. Amer. J. Dis. Child., 117: 54 (1969)

3. Berman, J. L., and Ford, R.: Intelligence quotients and intelligence loss in patients with phenylketonuria and some variant states. J. Pediat., 77: 764 (1970)

4. Blaskovics, M. E., and Shaw, K.N.F.: Hyperphenylalaninemia Methods for differential diagnosis. In: H. Bickel, F. P. Hudson, and L. I. Woolf: Phenylketonuria, p. 98 (Georg Thieme Verlag, Stuttgart, 1971)

5. Blau, K.: Aromatic acid excretion in phenylketonuria: Analysis of the unconjugated aromatic acids derived from phenylalanine. Clin. Chim. Acta, 27: 5 (1970).

6. Clow, C., Scriver, C. R., and Davies, E.: Results of mass screening for hyperaminoacidemias in the newborn infant. Amer. J. Dis. Child., 117: 48 (1969).

7. Cunningham, G. C., Day, R. W., Berman, J. L., and Hsia, D. Y.-Y. Phenylalanine tolerance tests: In families with phenylketonuria and hyperphenylalaninemia. Amer. J. Dis. Child., 117: 626 (1969).

8. Curtius, H. C, Völlmin, J. A, and Baerlocher, K.: The use of deuterated phenylalanine for the elucidation of the phenylalanine-tyrosine metabolism. Clin. Chim. Acta, 37: 277 (1972).

9. Friedman, P. A., Fisher, D. B., Kang E. S., and Kaufman, S.: Detection of hepatic phenylalanine 4-hydroxylase in classical phenylketonuria. Proc. Nat. Acad. Sci. U.S.A., 70: 552 (1973).

10. Güttler, F., and Rosleff, F.: Urinary phenylalanine excretion in hyperphenylalaninemic children. Acta Paediat. Scand., 62: 333 (1973).

11. Güttler, F., and Wamberg, E.: Persistent hyperphenylalaninemia Acta Paediat. Scand., 61: 321 (1972).

12. Hjalmarsson, O., Jagenburg, R., and Rödjer, S.: Mild and severe PKU: Comparative studies in two infants. Acta Paediat. Scand., 60: 11 (1971).

13. Hsia, D. Y.-Y.: Phenylketonuria and its variants. Progr. Med. Genet., 7: 29 (1970)

14. Hudson, F. P., Dickinson, R. A., and Ireland, J. T.: Experiences in the detection and treatment of phenylketonuria. Pediatrics, 31 : 47 (1963).

15. Jervis, G. A.: Phenylpyruvic oligophrenia: deficiency of phenylala- nine-oxidising system. Proc. Soc. Exp. Biol., 82: 514 (1953).

16. Justice, P., O'Flynn, M. E., and Hsia, D. Y.-Y.: Phenylalanine-hydroxylase activity in hyperphenylalaninaemia. Lancet, $i$ : 928 (1967).

17. Kang, E. S., Kaufman, S., and Gerald, P. S.: Clinical and biochemical observations of patients with atypical phenylketonuria. Pediatrics, 45: 83 (1970).

18. Karoum, F., Anah, C. O., Ruthven, C. R. J., and Sandler, M. Further observations on the gas-chromatographic measurement of urinary phenolic and indolic metabolites. Clin. Chim. Acta, 24: 341 (1969)

19. Kaufman, S., and Max, E. E.: Studies on the phenylalanine hydroxylating system in human liver and their relationship to pathogenesis of PKU and hyperphenylalaninemia. In: H. Bickel, F. P. Hudson, and L. I. Woolf: Phenylketonuria, p. 13 (Georg Thieme Verlag, Stuttgart, 1971).

20. Knox, W. E.: Phenylketonuria. In: J. B. Stanbury, J. B Wyngaarden, and D. S. Fredrickson: The Metabolic Basis of Inherited Diseases Ed. 3, p. 266 (McGraw-Hill, New York, 1972).

21. Levy, H. L., Shih, V. E., Karolkewicz, V., French, W. A., Carr, J R., Cass, V., Kennedy, J. L., and MacCready, R. A.: Persistent mild hyperphenylalaninemia in the untreated state: A prospective study. New Engl. J. Med., 285: 424 (1971).

22. Lines, D. R., and Waisman, H. A.: Urinary amino acid excretion in phenylketonuric, hyperphenylalaninemic, and normal patients. J. Pediat., 78: 474 (1971).

23. Menkes, J. H., and Holtzman, N. A.: Neonatal hyperphenylalaninemia: a differential diagnosis. Neuropädiatrie, $l: 434$ (1970)

24. O'Flynn, M. E., Tillman, P., and Hsia, D. Y.-Y.: Hyperphenylalaninemia without phenylketonuria. Amer. J. Dis. Child., 113: 22 (1967).

25. Rampini, S., Anders, P. W., Curtius, H.-C., and Marthaler, T.: Detection of heterozygotes for phenylketonuria by column chromatography and discriminatory analysis. Pediat. Res., 3: 287 (1969).

26. Rampini, S., Völlmin, J. A., Bosshard, H. R., Müller, M., and Curtius, H. C.: Unpublished data.

27. Rosenberg, L. E., and Scriver, C. R.: The hyperphenylalaninemias. In: P. K. Bondy: Duncan's Diseases of Metabolism, Ed. 6, p. 476 (W. B. Saunders, Philadelphia, 1969).

28. Schneider, A. J., and Garrard, S. D.: Diagnostic and therapeutic implications of persistent hyperphenylalaninemia in an infant heterozygous for the gene of phenylketonuria. J. Pediat., 68: 704 (1966).

29. Szeinberg, A., Cohen, B. E., Golan, R., Peled, I., Lavi, U., and Crispin, M.: Persistent mild hyperphenylalaninemia in various ethnic groups in Israel. Amer. J. Dis. Child., 118: 559 (1969).

30. Tada, K., Yoshida, T., Mochizuki, K., Konno, T., Nakagawa, H., Yokoyama, Y., Takada, G., and Arakawa, T.: Two siblings of hyperphenylalaninemia: suggestion to a genetic variant of phenylketonuria. Tohoku J. Exp. Med., 100: 249 (1969).

31. Thalhammer, O., Scheibenreiter, S, and Biedl, E.: Ueber das österreichische Programm zur Früherfassung angeborener Stoffwechselanomalien. Wien. klin. Wschr. 82: 1 (1970).

32. Völlmin, J. A., Bosshard, H. R., Müller, M., Rampini, S., and Curtius, H.-C.: Determination of urinary aromatic acids by gas chromatography: Results from healthy infants and from patients with phenylketonuria. Z. Klin Chem 0.402 (1971).

33. Wadman, S. H., van Sprang, F. J., van der Heiden, C., and Ketting, D.: Quantitation of urinary phenylalanine metabolites in phenylketonuria (PKU); In: H. Bickel, F. P. Hudson, and L. I. Woolf: Phenylketonuria, p. 65 (Georg Thieme Verlag, Stuttgart, 1971).

34. Williams, C. M., and Sweeley, C. C.: Gas chromatography of urinary aromatic acids. In: $H$. A. Szymanski: Biomedical Applications of Gas Chromatography, p. 225 (Plenum Press, New York, 1964)

35. Woolf, L. I., Ounsted, C., Lee, D., Humphrey, M. Cheshire, N. M., and Steed, G. R.: Atypical phenylketonuria in sisters with normal offspring. Lancet, ii: 464 (1961).

36. Yu, J. S., Stuckey, S. J., and O'Halloran, M. T.: Atypical phenylketonuria: An approach to diagnosis and management. Arch. Dis. Childhood, 45: 561 (1970).

37. Requests for reprints should be addressed to: S. Rampini, M.D., Stadtspital Triemli, Birmens dorferstrasse 497, 8063 Zürich, Switzerland.

38. Accepted for publication February 28, 1974 